\title{
Upaya Meningkatkan Kemampuan Berpikir Geometri Van Hiele Siswa SMP Melalui Model Pembelajaran Example Non Examples Nanang Suherman
}

\author{
Prodi Pendidikan Matematika, UIN Sunan Gunung Djati Bandung, \\ Jl. A.H. Nasution No. 105, Bandung 40614, Indonesia \\ ${ }^{a}$ E-mail: nanangsuherman@gmail.com
}

\begin{abstract}
Abstrak. Pokok bahasan geometri yang berhubungan dengan visualisasi gambar seringkali mengakibatkan siswa tidak senang dalam menghadapi pelajaran matematika. Jika dihubungkan dengan kemampuan berpikir matematis maka kemampuan yang paling cocok untuk dikembangkan berdasarkan masalah tersebut adalah kemampuan berpikir geometri Van Hiele. Tahapan berpikir geometri Van Hiele terdiri dari tahap pengenalan, analisis, pengurutan dan deduksi. Untuk mengaplikasikannya peneliti menggunakan model pembelajaran Example non Examples yang sejalan dengan berpikir geometri Van Hiele karena menggunakan media gambar. Tujuan penulisan skripsi ini adalah untuk mengetahui aktifitas guru dan siswa di kelas, kemampuan berpikir geometri Van Hiele siswa, dan sikap siswa. Subjek pada penelitian ini adalah siswa SMPN 8 Bandung kelas VIII-C semester 2 tahun ajaran 2011/2012. Instrumen yang digunakan adalah tes hasil belajar yang berupa tes formatif dan post tes. Untuk memperoleh data mengenai sikap siswa digunakan angket skala sikap. Dari hasil penelitian, diperoleh kesimpulan bahwa aktifitas guru dan siswa mengalami peningkatan untuk setiap siklus, kemampuan berpikir geometri Van Hiele siswa untuk setiap siklus pada sebagian besar siswa tergolong penguasaan tinggi dan lengkap, kemampuan berpikir geometri Van Hiele siswa diseluruh siklus pada sebagian besar siswa tergolong penguasaan tinggi dan lengkap. Dan hampir seluruh siswa bersikap positif terhadap pelajaran matematika, pembelajaran Example non Examples, dan soalsoal geometri Van Hiele. Terlihat dari rata-rata skor sikap siswa untuk setiap indikator selalu lebih besar dari pada skor netral siswa.
\end{abstract}

Kata Kunci. Kemampuan Berpikir Geometri Van Hiele, Pembelajaran Example Non Example

\section{Pendahuluan}

Pembelajaran Matematika di sekolah merupakan salah satu mata pelajaran yang mampu membekali siswa untuk berpikir logis, analitis, sistematis, kritis, dan kreatif serta mempunyai kemampuan bekerja sama. Salah satu cabang matematika yang diajarkan di sekolah adalah geometri. Pembelajaran geometri dapat menumbuhkembangkan kemampuan berpikir logis, juga efektif untuk membantu menyelesaikan permasalahan dalam banyak cabang matematika. Suydam (Thohari,1992:2) mengungkapkan bahwa geometri merupakan bagian dari matematika yang dapat mengembangkan kemampuan berpikir logis.
Banyak faktor penyebab rendahnya prestasi siswa dalam geometri. Burger\& Shaughnessy (Thohari,1992:2) mengatakan bahwa rangkaian pengajaran memiliki pengaruh positif terhadap keberhasilan siswa. Apabila aktivitas-aktivitas awal pengajaran mengecewakan dan tidak menarik, maka para siswa mungkin tidak akan termotivasi untuk mempelajari apa yang ingin diajarkan guru kepada mereka. Begitu pula Usiskin, Burger dan Shaughnessy (Thohari,1992:2), mengatakan kualitas dari pengajaran merupakan salah satu faktor yang mempunyai pengaruh paling besar terhadap prestasi siswa dalam geometri. 
Salah satu tahapan kemampuan berpikir geometri siswa yang popular yaitu tahapan berpikir geometri Van Hiele. Tahapan berpikir geometri Van Hiele (Van de Walle,2008:151-154) terdiri dari (1) tingkat visualisasi(pengenalan), (2) tingkat analisis, (3) tingkat deduksi informal(pengurutan), (4) tingkat deduksi, (5) tingkat rigor.

Untuk mendukung pembelajaran geometri agar sesuai dengan tujuan pembelajarannya maka perlu diterapkan model-model pembelajaran yang relevan. Salah satu model pembelajaran yang dirasa relevan menurut peneliti dalam meningkatkan tahapan bepikir geometri siswa adalah model pembelajaran Example non Examples yang berbasis gambar. Berkaitan dengan tahapan berpikir geometri Van Hiele, pembelajaran Example non Examples mempunyai karakteristik yang sangat cocok. Yaitu adanya visualisasi dari setiap permasalah yang diberikan. Hal ini sejalan dengan tahapan berpikir geometri Van Hiele yang pada setiap tingkatan memerlukan adanya visualisasi.

\section{Metodologi Penelitian}

Metode Penelitian yang digunakan dalam penelitian ini adalah metode Penelitian Tindakan Kelas. Populasi dalam penelitian ini yaitu seluruh siswa kelas VIII SMPN 8 Bandung. Sampel diperoleh dengan cara dipilih yaitu kelas VIII C sebagai sampel penelitian dengan jumlah peserta didik 43 siswa. Teknik pengumpulan data adalah tes subjektif selama lima siklus yaitu Siklus I, Siklus II, Siklus III, Siklus IV, Siklus V, Post tes, penyebaran angket skala sikap, dan lembar observasi aktivitas siswa dan guru.

\section{Hasil dan Pembahasan}

Pembelajaran Example non Examples merupakan suatu model pembelajaran berbasis masalah (Problem based learning). Suatu strategi pembelajaran yang menggunakan masalah dunia nyata sebagai suatu konteks bagi siswa untuk belajar tentang berpikir dan keterampilan pemecahan masalah, serta untuk memperoleh pengetahuan dan konsep yang esensi dari mata pelajaran.

Example non Examples secara arti kata berarti contoh bukan contoh, artinya bahwa metode ini memberikan materi dengan contoh dari materi tersebut, sekaligus bukan contohnya agar siswa lebih memahami. Misalkan prisma yang memiliki alas berbentuk segiempat contohnya kubus dan balok, sedangkan bukan contohnya adalah tabung karena tabung alasnya berbentuk lingkaran.

Komalasari (2011: 61) mengemukakan Example non Examples merupakan pembelajaran yang mengutamakan kepekaan siswa terhadap permasalahan yang ada di sekitarnya melalui analisis contoh-contoh berupa gambar-gambar yang bermuatan masalah. Siswa diarahkan untuk mengidentifikasi masalah, mencari alternatif pemecahan masalah, dan menentukan cara pemecahan masalah yang paling efektif, serta melakukan tindak lanjut.

Kelebihan dari metode ini adalah adanya visualisasi gambar-gambar pada setiap proses pembelajaran. Tentunya hal ini sangat mendukung materi geometri. Dengan adanya visualisasi siswa akan terlatih untuk dapat membayangkan dalam benaknya jika diberikan permasalahan yang tidak disertai dengan gambarnya.

Dalam proses pembelajaran penggunaan media gambar dapat memberikan kesempatan siswa untuk aktif, kreatif dan menemukan sendiri. Sudjana dan Rivai (Kartiningsih, 2011: 13) mengungkapkan beberapa kelebihan pembelajaran dengan menggunakan media gambar sebagai berikut:

1. Konkrit, lebih realistis dan menunjukan pokok masalah atau 
pesan yang akan dikomunikasikan bila dibandingkan media verbal.

2. Dapat mengatasi batasan ruang dan waktu

3. Dapat mengatasi keterbatasan indera

4. Dapat memperjelas suatu masalah yang kompleks

5. Murah harganya dan mudah diperoleh

Dari penjelasan-penjelasan yang disampaikan maka dapat dikatakan sangat cocok pemilihan model pembelajaran Example non Examples dengan materi geometri khususnya kubus, balok, prisma dan limas yang disampaikan pada penelitian yang akan dilaksanakan. Menurut Komalasari (2011:61-62) langkah-langkah model pembelajaran Example non Examples:

a. Guru mempersiapkan gambar-gambar geometri tentang permasalahan yang sesuai dengan tujuan pembelajaran yakni gambar-gambar tentang kubus, balok, prisma dan limas.

Misalkan guru akan menerangkan rusuk dan bidang sisi kubus, maka guru dapat mempersiapkan gambar kubus dan dadu. Selain bentuk kubus, guru menampilkan bentuk yang bukan contohnya (non example) dari bentuk kubus yakni bangun ruang yang memiliki bentuk hampir sama namun memiliki sifat yang berbeda. Maka bentuk non example dari kubus, guru dapat menampilkan pula balok. Bentuk example dari kubus yaitu dadu dan bentuk non example nya yaitu bentuk balok, contohnya batu bata.

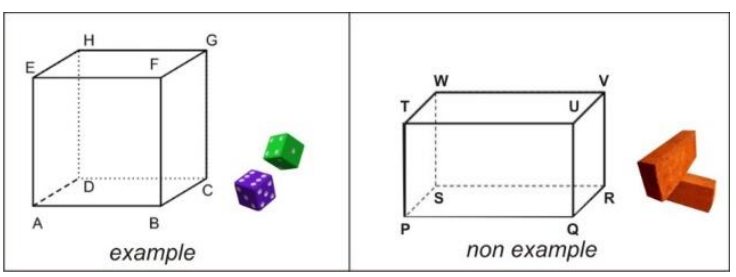

Gambar 1. Kubus dan Balok (non example dari kubus)
Perbedaaan sifat yang menjelaskan bahwa balok bentuk non example dari kubus dapat dilihat dari tabel berikut:

\begin{tabular}{|l|l|l|}
\hline \multirow{2}{*}{} & \multicolumn{2}{|c|}{ Aspek } \\
\cline { 2 - 3 } & Rusuk & Rusuk \\
\hline $\begin{array}{l}\text { Kubus } \\
\text { (example) }\end{array}$ & $\begin{array}{l}\text { Sama } \\
\text { panjang }\end{array}$ & $\begin{array}{l}\text { Berbentuk } \\
\text { persegi yang } \\
\text { kongruen }\end{array}$ \\
\hline $\begin{array}{l}\text { Balok } \\
\text { (non } \\
\text { example })\end{array}$ & $\begin{array}{l}\text { Ada yang } \\
\text { sama } \\
\text { panjang ada } \\
\text { yang berbeda }\end{array}$ & $\begin{array}{l}\text { Berbentuk } \\
\text { persegi atau } \\
\text { persegi } \\
\text { panjang }\end{array}$ \\
\hline
\end{tabular}

Tabel 1. Perbedaan aspek rusuk dan bidang sisi dari kubus dan balok

b. Guru menayangkan materi kubus, balok, prisma dan limas melalui powerpoint dan membagikan LKS kepada setiap siswa. Gambar 1. dan Gambar 2. dapat ditampilkan di powerpoint untuk pemahaman konsep dan membagikan LKS kepada setiap siswa. Bentuk LKS yang diberikan kepada siswa adalah untuk menuntun siswa dalam proses pembelajaran misalkan:

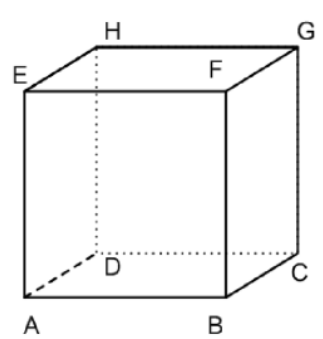

Gambar 2. Kubus

1. Rusuk-rusuk untuk kubus ABCDEFGH yaitu:

$\mathrm{AB}, \mathrm{BC}, \ldots, \ldots, \ldots$

Sehingga kubus ABCDEFGH mempunyai sebanyak .... Rusuk

2. Bidang sisi untuk kubus ABCDEFGH yaitu: 
$\mathrm{ABCD}, \mathrm{ABEF}, \ldots, \ldots, \ldots, \ldots$

Sehingga kubus ABCDEFGH mempunyai sebanyak .... Bidang sisi

c. Guru memberi petunjuk dan memberi kesempatan pada siswa untuk memperhatikan/menganalisis

permasalahan yang ada dalam gambar. Selain LKS, guru juga memberikan permasalahan, khususnya yang berkaitan dengan kehidupan sehari-hari. Misalkan guru memberikan gambar sebuah penampang bak mandi, siswa diminta mencari volume air yang dapat ditampung bak tersebut. Gambar berikut merupakan sebuah penampang bak mandi dengan ukuran panjang $2 \mathrm{~m}$, lebar $1 \mathrm{~m}$, dan tinggi $1,3 \mathrm{~m}$, kita akan mencari volume air yang dapat ditampung oleh bak tersebut. Siswa diberi kesempatan untuk menganalisis permasalahan tersebut, dan mencoba memecahkannya.

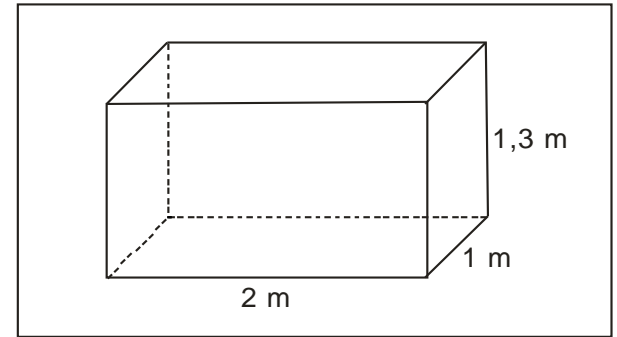

Gambar 3. Penampang Bak Mandi

Salah satu alternatif pemecahannya sebagai berikut:

Diketahui: bak mandi dengan ukuran panjang $2 \mathrm{~m}$, lebar $1 \mathrm{~m}$, dan tinggi $1,3 \mathrm{~m}$ Ditanyakan: volume air yang dapat ditampung bak mandi

Jawab:

$$
\begin{aligned}
V_{\text {balok }} & =p \times l \times t \\
& =2 \times 1 \times 1,3 \\
& =2,6 \mathrm{~m}^{3} \\
& =2600 \text { liter }
\end{aligned}
$$

Jadi volume air yang dapat ditampung bak dengan ukuran panjang $2 \mathrm{~m}$, lebar $1 \mathrm{~m}$, dan tinggi 1,3 $\mathrm{m}$ adalah 2600 liter.

Jurnal Analisa Vol.2 No.4 Juni 2016: 69-80 d. Melalui diskusi kelompok 2-3 orang siswa, siswa diminta berdiskusi bersama teman sebangkunya mengenai permasalahan yang diberikan dan diminta mencatat hasil pekerjaannya.

e. Tiap kelompok diberi kesempatan membacakan hasil diskusinya. Setelah siswa mencoba memecahkan permasalahan yang diberikan, siswa diberikan kesempatan untuk membacakannya di depan kelas. Misal setelah dapat memecahkan permasalahan sesuai dengan gambar 1.3 mencari volume air yang dapat ditampung bak mandi, siswa mempresentasikan hasil pekerjaannya di depan kelas.

f. Mulai dari komentar/hasil diskusi siswa, guru mulai menjelaskan materi sesuai dengan tujuan yang ingin dicapai. Setelah siswa mempresentasikan hasil pekerjaannya di depan kelas, guru baru mulai menjelaskan materi sesuai dengan tanggapan siswa. Sehingga inti dari pembelajaran Example non Examples, guru baru akan menjelaskan materi ketika siswa sudah menggali materi tersebut sesuai dengan kemampuan siswa masing-masing.

g. Kesimpulan. Setiap akhir pembelajaran, guru dan siswa bersamasama menyimpulkan materi yang telah dipelajari, kemudian diakhiri dengan pemberian tes formatif.

Pierre dan Dina Van Hiele adalah suami istri berkebangsaan Belanda. Mereka mengemukakan bahwa dalam belajar geometri, seseorang akan melalui lima tingkatan hierarkis. Lima tingkatan tersebut adalah level 1 (visualization), level 2 (analysis), level 3 (abstraction), level 4 (deduction), dan level 5 (rigor).

Dengan model pembelajaran yang tepat dalam menyampaikan materi geometri, 
siswa akan secara sistematis melewati kelima tahapan tingkatan geometri Van Hiele. Dimana siswa tidak dapat mencapai satu tingkatan pemikiran tanpa melewati tingkatan sebelumnya. Setiap tingkatan menunjukan kemampuan berpikir yang digunakan seseoran dalam belajar konsep geometri. Berikut ini tahapan-tahapan geometri Van Hiele (Van de Walle, 2008: 151-154):

\section{Tahap 1: level 0(Visualisasi)}

Tahap ini disebut juga tahap pengenalan (recognition). Pada tingkatan ini siswa mengenal dan menamakan bentuk-bentuk berdasarkan pada karakteristik luas dan tampilan dari bentuk-bentuk tersebut. Dengan demikian meskipun pada tahap ini siswa sudah mengenal nama suatu bangun, siswa belum mengamati ciri-ciri bangun dari bangun itu. Sebagai contoh, pada tahap ini siswa tahu suatu bangun bernama kubus, tetapi ia belum menyadari ciri-ciri dari bangun yang bernama kubus itu.

\section{Tahap 2: level 1(Analisis)}

Pada tahap ini siswa sudah mengenal bangun-bangun geometri berdasarkan sifat-sifat dari masing-masing geometri. Pada tingkat ini siswa sudah bisa menganalisis bagian-bagian suatu bangun dan mengamati sifat yang dimilikinya. Misalnya, siswa sudah mengetahi bahwa sisi-sisi yang sejajar pada balok memiliki panjang yang sama. Namun pada level ini siswa belum mengetahui hubungan yang terkait antara suatu bangun geometri dengan bangun geometri yang lainnya.

Tahap 3: level 2(pengurutan/deduksi informal)
Pada tahap ini, siswa sudah bisa memahami hubungan antara ciri yang satu dengan ciri yang lain pada suatu bangun. Siswa mulai dapat berpikir tentang membuat hubungan diantara sifat-sifat tersebut. Jika bentuknya kubus, bangun tersebut juga merupakan balok, karena mempunyai 3 pasang sisi yang sejajar.

Tahap 4: level 3 (deduksi)

Pada tingkat ini, cara berpikir deduktif, siswa lebih diarahkan pada pemikiran jikamaka. Misalkan jika panjang, lebar, dan tinggi suatu kubus diketahui maka kita dapat mencari luas permukaan dan volumenya.

Tahap 5: level 4 (ketepatan/rigor)

Pada level ini siswa sudah dapat memahami bahwa adanya ketepatan dari sesuatu yang mendasari itu penting. Misalnya, ketepatan dari aksioma-aksioma yang menyebabkan terjadi geometri dari Euclid. Level ini tidak digunakan pada penelitian yang akan dilaksanakan karena level ini belum ada pada tingkatan sekolah menengah.

Sehingga indikator kemampuan berpikir geometri Van Hiele siswa yang diukur yaitu tahap pengenalan, analisis, pengurutan, dan deduksi.

Penelitian di SMPN 8 Bandung dilaksanakan dalam 6 kali pertemuan. Secara lengkap jadwal pelaksanaan penelitian disajikan pada tabel berikut:

Tabel 2. Jadwal Pelaksanaan Penelitian

\begin{tabular}{|l|l|l|}
\hline Pertemuan & Waktu & Kegiatan \\
\hline 1 & Senin, 7 Mei 2012 & Pelaksanaan rencana pembelajaran pada siklus I \\
\hline
\end{tabular}




\begin{tabular}{|l|l|l|}
\hline & $07.00-08.20$ & \\
\hline 2 & $\begin{array}{l}\text { Sabtu, 12 Mei 2012 } \\
07.00-08.20\end{array}$ & Pelaksanaan rencana pembelajaran pada siklus II \\
\hline 3 & $\begin{array}{l}\text { Sabtu, 19 Mei 2012 } \\
07.00-08.20\end{array}$ & Pelaksanaan rencana pembelajaran pada siklus III \\
\hline 4 & $\begin{array}{l}\text { Senin, 21 Mei 2012 } \\
07.00-08.20\end{array}$ & Pelaksanaan rencana pembelajaran pada siklus IV \\
\hline 5 & $\begin{array}{l}\text { Sabtu, 26 Juni 2012 } \\
07.00-08.20\end{array}$ & $\begin{array}{l}\text { Pelaksanaan rencana pembelajaran pada siklus V } \\
07.00-08.20\end{array}$ \\
\hline 6 & $\begin{array}{l}\text { Senin, 28 Juni 2012 } \\
\text { sikap }\end{array}$ \\
\hline
\end{tabular}

Adapun secara keseluruhan aktivitas siswa selama pembelajaran menggunakan model pembelajaran Example non Examples selau mengalami peningkatan pada tiap siklus. Kondisi ini menggambarkan bahwa siswa merasa senang dan mampu mengikuti kegiatan proses pembelajaran. Rata-rata persentase aktivitas siswa pada setiap pembelajaran disajikan pada tabel berikut:

Tabel 3. Persentase Aktivitas Siswa Setiap Siklus

\begin{tabular}{|c|c|c|c|c|c|c|c|}
\hline \multirow{2}{*}{ No } & \multirow{2}{*}{$\begin{array}{c}\text { Indikator } \\
\text { Aktivitas } \\
\text { Siswa }\end{array}$} & \multicolumn{5}{|c|}{ Persentase untuk Setiap Siklus } & \multirow{2}{*}{$\begin{array}{c}\text { Rata-rata } \\
\text { seluruh } \\
\text { siklus }\end{array}$} \\
\hline & & Siklus I & Siklus II & Siklus III & Siklus IV & Siklus V & \\
\hline 1 & 1 & 57 & 62,21 & 70 & 80,23 & 87 & \\
\hline 2 & 2 & 59,3 & 65,7 & 71 & 74,42 & 83 & \\
\hline 3 & 3 & 52 & 63,4 & 73,3 & 78,5 & 84,3 & \\
\hline 4 & 4 & 54,1 & 61,05 & 73,3 & 82,6 & 86 & \\
\hline 5 & 5 & 55,8 & 64 & 68 & 82 & 86 & \\
\hline 6 & 6 & 54,7 & 60,5 & 66,3 & 82,56 & 88 & \\
\hline \multicolumn{2}{|c|}{ Rata-rata $(\%)$} & 55,52 & 62,79 & 70,35 & 80,04 & 86,66 & 70,87 \\
\hline
\end{tabular}

Secara keseluruhan aktivitas guru selama pembelajaran menggunakan pembelajaran Example non Examples mengalami peningkatan, dapat dilihat pada tabel berikut: 
Tabel 4. Aktivitas Guru Selama pembelajaran Menggunakan Model Pembelajaran Example non Examples

\begin{tabular}{|c|c|c|c|c|}
\hline \multirow{2}{*}{ Siklus } & \multicolumn{4}{|c|}{ Penilaian (\%) } \\
\hline & $\mathbf{A}$ & $\mathbf{B}$ & $\mathbf{C}$ & D \\
\hline I & 17 & 17 & 67 & 0 \\
\hline II & 17 & 50 & 33 & 0 \\
\hline III & 25 & 78 & 0 & 0 \\
\hline IV & 42 & 61 & 0 & 0 \\
\hline $\mathrm{V}$ & 75 & 25 & 0 & 0 \\
\hline
\end{tabular}

Pada tabel diatas, terlihat bahwa aktifitas guru pada siklus $\mathrm{V}$ menunjukan peningkatan dibandingkan siklus sebelumnya yaitu semakin baik.

Pelaksanaan tes tiap siklus (formatif) dilakukan sebanyak lima kali, yaitu tes siklus I, tes siklus II, tes siklus III, tes siklus IV, dan tes siklus V. Tes formatif dilaksanakan seriap akhir pembelajaran. Kemudian setelah seluruh siklus selesai, maka diadakan post tes. Adapun tujuannya adalah untuk mengetahui peningkatan kemampuan berpikir geometri Van Hiele siswa selama proses kegiatan belajar mengajar dengan menggunakan model pembelajaran Example non Examples.

Berdasarkan hasil perhitungan data tes formatif dan post tes, diperoleh ketuntasan belajar siswa secara klasikal, daya serap siswanya dan nilai rata-rata kemampuan berpikir geometri Van Hiele. KKM yang berlaku di sekolah yaitu 70, sehingga dapat diketahui siswa yang tuntas yang tidak tuntas. Siswa yang tidak tuntas disebabkan karena belum dapat mengerjakan soal dengan benar dengan nilai minimal 70 . Tindak lanjut guru untuk siswa yang belum tuntas mengikuti pembelajaran adalah dengan memberikan perhatian lebih seperti memantau, memotivasi, dan memberikan bimbingan selama proses pembelajaran berlangsung.

Untuk lebih jelasnya mengenai ketuntasan belajar siswa pada setiap siklus dan pada Post tes dapat dilihat pada tabel berikut:

Tabel 5. Ketuntasan Siswa Setiap Siklus dan Post tes

\begin{tabular}{|c|c|c|c|c|c|c|c|c|}
\hline No. & $\begin{array}{l}\text { Tes } \\
\text { Evaluasi }\end{array}$ & $\begin{array}{l}\text { Ketuntasan } \\
\text { belajar } \\
\text { klasikal }\end{array}$ & $\begin{array}{l}\text { Daya } \\
\text { serap } \\
\text { siswa }\end{array}$ & $\begin{array}{l}\text { Rata-rata } \\
\text { kemampuan } \\
\text { Van Hiele }\end{array}$ & KKM & $\begin{array}{l}\text { Ketuntasan } \\
\text { secara } \\
\text { klasikal }\end{array}$ & $\begin{array}{l}\text { Jumlah } \\
\text { siswa } \\
\text { tuntas }\end{array}$ & $\begin{array}{l}\text { Jumlah } \\
\text { siswa } \\
\text { tidak } \\
\text { tuntas }\end{array}$ \\
\hline 1. & Siklus I & 83,72 & 71,28 & 81,63 & \multirow{6}{*}{70} & Tuntas & 36 & 7 \\
\hline 2. & Siklus II & 88,37 & 76,63 & 83,49 & & Tuntas & 38 & 5 \\
\hline 3. & $\begin{array}{l}\text { Siklus } \\
\text { III }\end{array}$ & 90,70 & 77,09 & 84,07 & & Tuntas & 39 & 4 \\
\hline 4. & $\begin{array}{l}\text { Siklus } \\
\text { IV }\end{array}$ & 90,70 & 77,60 & 83,72 & & Tuntas & 39 & 4 \\
\hline 5. & Siklus V & 95,35 & 811,28 & 84,07 & & Tuntas & 41 & 2 \\
\hline 6. & $\begin{array}{l}\text { Tes } \\
\text { Akhir }\end{array}$ & 100 & 89,21 & 91,11 & & Tuntas & 43 & 0 \\
\hline
\end{tabular}


Pada Tabel 5 secara klasikal pada setiap siklus siswa dianggap telah tuntas, walaupun dilihat dari nilai rata-rata masih ada beberapa siswa yang belum tuntas. Jumlah siswa yang tuntas pada setiap siklus mengalami peningkatan, ini menunjukan bahwa terjadi peningkatan kemampuan berpikir geometri Van Hiele siswa.
Adapun perkembangan kemampuan berpikir geometri Van Hiele siswa dapat dilihat dari rata-rata persentase nilai tes tiap siklus. Secara keseluruhan rata-rata persentase hasil tes tiap siklus dan tes akhir disajikan pada tabel berikut:

Tabel 6. Perkembangan Kemampuan Berpikir Geometri Van Hiele Siswa

\begin{tabular}{|l|l|l|l|l|l|l|l|l|l|}
\hline \multirow{2}{*}{ No. } & \multirow{2}{*}{$\begin{array}{l}\text { Tes } \\
\text { Evaluasi }\end{array}$} & \multicolumn{7}{|c|}{ Berpikir Van Hiele } \\
\cline { 3 - 10 } & & Pengenalan & Kriteria & Analisis & Kriteria & Pengurutan & Kriteria & Deduksi & Kriteria \\
\hline 1 & Siklus I & 73,35 & tinggi & 100 & lengkap & 63,95 & sedang & 82,79 & tinggi \\
\hline 2 & Siklus II & 72,09 & tinggi & 91,86 & lengkap & 90,70 & lengkap & 92,81 & lengkap \\
\hline 3 & Siklus III & 72,07 & tinggi & 100 & lengkap & 73,26 & tinggi & 84,88 & tinggi \\
\hline 4 & Siklus IV & 86,82 & lengkap & 100 & lengkap & 100 & lengkap & 84,79 & tinggi \\
\hline 5 & Siklus V & 77,33 & tinggi & 96,90 & lengkap & 88,37 & tinggi & 82,24 & tinggi \\
\hline 6 & Tes Akhir & 99,42 & lengkap & 93,15 & lengkap & 86,58 & lengkap & 85,29 & lengkap \\
\hline
\end{tabular}

Pada tabel terlihat bahwa kriteria untuk setiap siklus dan setiap tingkatan indikator berpikir Van Hiele bervariatif. Namun secara keseluruhan pada setiap siklus temasuk kategori tinggi dan lengkap.
Sikap siswa terhadap pelajaran matematika, pembelajaran Example non Examples dan soal-soal geometri Van Hiele secara keseluruhan terlihat seperti tabel berikut:

Tabel 7. Rekapitulasi Sikap Siswa Secara Keseluruhan

\begin{tabular}{|l|l|l|l|}
\hline Sikap & $\begin{array}{l}\text { Rata-rata } \\
\text { Skor Netral }\end{array}$ & $\begin{array}{l}\text { Rata-rata } \\
\text { Skor Siswa }\end{array}$ & Kesimpulan \\
\hline $\begin{array}{l}\text { Terhadap pelajaran } \\
\text { matematika }\end{array}$ & 2,625 & 3,360 & Positif \\
\hline $\begin{array}{l}\text { Terhadap pembelajaran } \\
\text { Example non Examples }\end{array}$ & 2,429 & 3,101 & Positif \\
\hline $\begin{array}{l}\text { Terhadap soal-soal } \\
\text { geometri Van Hiele }\end{array}$ & 2,333 & 2,868 & Positif \\
\hline RERATA & $\mathbf{2 , 4 6 2}$ & $\mathbf{3 , 1 0 9}$ & Positif \\
\hline
\end{tabular}


Sikap siswa terhadap pelajaran matematika, pembelajaran Example non Examples, dan terhadap soal-soal geometri Van Hiele menunjukan sikap positif. Hal ini ditunjukan dengan rata-rata skor siswa lebih besar dibandingkan dengan rata-rata skor netral.

Berdasarkan hasil dari analisis data, maka diperoleh beberapa penemuan, diantaranya yaitu peningkatan aktifitas siswa dan guru selama proses pembelajaran Example non Examples, peningkatan kemampuan berpikir geometri Van Hiele siswa, dan sikap siswa terhadap pembelajaran Example non Examples.

Peningkatan yang terjadi sangatlah didukung dengan model pembelajaran yang dilaksanakan. Dengan model pembelajaran Example non Examples, siswa diajak untuk menggali berbagai permasalahan dengan cara melihat permasalahan itu dalam bentuk gambar. Dengan berbagai kelebihannya, media gambar mampu meningkatkan minat siswa dalam proses pembelajaran. Siswa merasa tertarik dengan gambar-gambar yang ditayangkan. Selain itu, peningkatanpeningkatan yang terjadi disebabkan optimalnya seorang guru dalam

melaksanakan pembelajaran sesuai dengan langkah-langkah model pembelajaran. Hal yang menarik ataupun yang disukai siswa dalam suatu model pembelajaran sangat berpengaruh dalam peningkatan kegiatan pembelajaran. Dengan model pembelajaran yang menarik dan peran guru yang maksimal, membuat siswa menunjukan sikap positif terhadap pembelajaran yang telah dilaksanakan.

Berikut ini beberapa kelebihan dan kesulitan dari pembelajaran Example non Examples berdasarkan penelitian yang telah dilaksanakan:

1) Kelebihan a) Pembelajaran Example non Examples memberikan kesempatan kepada siswa untuk menggali materi yang dipelajari secara lebih luas.

b) Pembelajaran Example non Examples menyederhanakan permasalahan yang kompleks menjadi lebih sederhana dengan menggunakan gambar-gambar yang ditampilkan melalui infokus.

c) Pengelompokan secara berpasangan akan lebih mengefektifkan diskusi dibandingkan dengan diskusi kelompok yang lebih banyak anggotanya.

d) Gambar-gambar yang ditampilkan melalui infokus dapat membuat siswa lebih tertarik dalam kegiatan belajar mengajar.

e) Presentasi di depan kelas melatih siswa untuk dapat berbicara di depan umum.

f) Media gambar merupakan media yang sederhana tetapi sangat baik untuk mempermudah menyampaikan suatu materi bangun ruang.

2) Kesulitan

a) Siswa seringkali menggambar bangun geometri secara asal-asalan tidak menggunakan penggaris, karena mereka tidak membawa penggaris. Sehingga diperlukan alat tulis yang lengkap. 
b) Setiap pertemuan harus menyediakan gambargambar yang menarik agar disukai siswa.

c) Soal-soal yang dibuat mengandung indikator Van Hiele yang harus saling relevan.

d) Ketika presentasi di depan kelas, seringkali hanya siswa tertentu yang tampil ke depan kelas untuk mempresentasikan hasil diskusinya.

e) Harus adanya infokus di dalam kelas, agar lebih mudah memperlihatkan gambar-gambar kepada siswa.

f) Peralatan yang harus lengkap di kelas, seperti penggaris dan papan tulis bergaris untuk mempermudah

menggambar bangun ruang.

g) Pengelompokan secara berpasangan membuat guru harus lebih banyak berkeliling untuk memantau semua kelompok.

\section{Simpulan}

Berdasarkan analisis data hasil penelitian tentang peningkatan kemampuan berpikir geometri Van Hiele siswa melalui model pembelajaran Example non Examples pada pokok bahasan bangun ruang, diperoleh kesimpulan, yaitu: Aktifitas guru dan siswa di kelas VIII-C SMPN 8 Bandung dengan menggunakan model pembelajaran Example non Examples mengalami peningkatan pada setiap siklus. Dengan adanya peningkatan aktifitas siswa pada setiap siklus, berarti siswa sudah secara bertahap menyukai dan menyenangi kegiatan pembelajaran dengan menggunakan model pembelajaran Example non Examples.

Kemampuan berpikir geometri Van Hiele siswa pada tiap siklus dengan menggunakan model pembelajaran Example non Examples diperoleh sebagai berikut:

\section{a. Siklus I}

Kemampuan berpikir geometri Van Hiele siswa pada siklus I berdasarkan indikator berpikir geometri Van Hiele pada level pengenalan termasuk penguasaan tinggi, level analisis termasuk penguasaan lengkap, level pengurutan termasuk penguasaan sedang, dan level deduksi termasuk penguasaan tinggi.

\section{b. Siklus II}

Kemampuan berpikir geometri Van Hiele siswa pada siklus II berdasarkan indikator berpikir geometri Van Hiele pada siklus II level pengenalan termasuk penguasaan tinggi, level analisis termasuk penguasaan lengkap, level pengurutan termasuk penguasaan lengkap, dan level deduksi termasuk penguasaan lengkap.

\section{c. Siklus III}

Kemampuan berpikir geometri Van Hiele siswa pada siklus III berdasarkan indikator berpikir geometri Van Hiele pada siklus III level pengenalan termasuk penguasaan tinggi, level analisis termasuk penguasaan lengkap, level pengurutan termasuk penguasaan tinggi, dan level deduksi termasuk penguasaan tinggi.

\section{d. Siklus IV}

Kemampuan berpikir geometri Van Hiele siswa pada siklus IV berdasarkan indikator berpikir geometri Van Hiele pada siklus IV level pengenalan termasuk penguasaan lengkap, level analisis termasuk penguasaan lengkap, level pengurutan 
termasuk penguasaan lengkap, dan level deduksi termasuk penguasaan lengkap.

\section{e. Siklus V}

Kemampuan berpikir geometri Van Hiele siswa pada siklus $\mathrm{V}$ berdasarkan indikator berpikir geometri Van Hiele pada siklus V level pengenalan termasuk penguasaan tinggi, level analisis termasuk penguasaan lengkap, level pengurutan termasuk penguasaan lengkap, dan level deduksi termasuk penguasaan tinggi.

Kemampuan berpikir geometri Van Hiele siswa dengan menggunakan model pembelajaran Example non Examples di seluruh siklus pada level pengenalan termasuk penguasaan lengkap, level analisis termasuk penguasaan lengkap, level pengurutan termasuk penguasaan lengkap, dan level deduksi termasuk penguasaan lengkap. Sehingga secara keseluruhan pada tes akhir, kemampuan berpikir geometri Van Hiele siswa termasuk kedalam penguasaan lengkap.

Sikap siswa terhadap pembelajaran dengan menggunakan model pembelajaran Example non Examples berdasarkan hasil analisis lembar skala sikap diperoleh bahwa siswa memiliki sikap positif terhadap pelajaran matematika, pembelajaran Example non Examples, dan soal-soal geometri Van Hiele. Hal ini dapat dilihat dari rata-rata skor sikap siswa untuk setiap indikator selalu lebih besar dari pada skor netral siswa.

Berdasarkan hasil penelitian, pembahasan dan kesimpulan yang telah dikemukakan, maka dapat dikemukakan bahwa model pembelajaran Example non Examples merupakan salah satu alternatif yang bisa digunakan guru matematika dalam menyajikan materi matematika terutama materi yang menggunakan media gambar untuk meningkatkan kemampuan berpikir geometri Van Hiele. Agar proses pembelajaran dapat memberikan peningkatan kualitas pembelajaran, sebaiknya guru membuat perencanaan yang baik mengenai model pembelajaran dan memilih materi yang sesuai dengan model pembelajaran yang akan digunakan. Hal tersebut dikarenakan tidak semua materi matematika cocok menggunakan model pembelajaran Example non Examples.

Pada penelitian ini aspek yang diukur adalah kemampuan berpikir geometri Van Hiele siswa dengan menggunakan model pembelajaran Example non Examples, oleh karena itu disarankan kepada para peneliti selanjutnya agar menggunakan model pembelajaran lain serta aspek yang belum terukur hendaknya menjadi bahan pemikiran untuk dijadikan penelitian.

\section{Daftar Pustaka}

Adinawan, M. Cholik. (2007). Matematika untuk SMP Kelas VIII Semester 2. Jakarta: Erlangga

Agus, Nuniek Avianti. (2008). Mudah belajar Matematika kelas VIII. Jakarta: Pusat Perbukuan Departemen Pendidikan Nasional

Anugrah, K. (2011). Peningkatan Level Berpikir Geometri Van Hiele Melalui Pembelajaran Berbasis Masalah Berbantuan Cabri Geometry. Skripsi FPMIPA UPI Bandung: Tidak Diterbitkan.

Arikunto, S. (2006). Prosedur Penelitian, Suatu Pendekatan Praktik. Jakarta: Rineka Cipta

Arikunto, S. (2009). Dasar-dasar Evaluasi Pendidikan. Jakarta: Bumi Aksara

Budi Rahaju, Endah. dkk. (2008). Matematika Kelas 2 SMP. Jakarta: Pusat Perbukuan Departemen Pendidikan Nasional

Hasan Bisri, Cik. (1998). Penuntun Penyusunan Rencana Penelitiandan Penulisan Skripsi 2. Jakarta: Logos Wacana Ilmu

Kariadinata, Rahayu. (2010). Statistika Penelitian Pendidikan. Bandung:

Jurnal Analisa Vol.2 No.4 Juni 2016: 69-80 
Diktat Perkuliahan UIN. Tidak Diterbitkan

Kartiningsih, Lilis. (2011). Upaya Meningkatkan Hasil Belajar Siswa Pada Konsep Benda Dan Sifatnya Melalui Model Picture To Picture. Skripsi FPMIPA UPI Bandung: Tidak Diterbitkan.

Komalasari, K. (2011). Pembelajaran Kontekstual Konsep dan Aplikasi. Bandung: Refika Aditama

Mulyasa, E. (2010). Praktik Penelitian Tindakan Kelas (menciptakan perbaikan berkesinambungan). Bandung: Rosda

NCTM. (2011). Standard for School Mathematics. Reston, VA: Authur. [Online]. Tersedia: http://www.nctm.org/standards/conte nt.aspx $? \mathrm{id}=26863 \quad[19$ Desember 2011]

Nuharini, Dewi. dkk. (2008). Matematika Konsep dan Aplikasinya. Jakarta: Pusat Perbukuan Departemen Pendidikan Nasional

Permendiknas. (2006). Standar Isi untuk Satuan Pendidikan Dasar dan Menengah. Jakarta: Sinar Grafika

Permendiknas. (2006). Standar Kompetensi Lulusan untuk Satuan Pendidikan Dasar dan Menengah. Jakarta: Sinar Grafika

Rosana, Sanny. (2008). Penerapan Pendekatan Reciprocal Teaching Dalam Pembelajaran Matematika
Untuk Meningkatkan Kemampuan Pemecahan Masalah Geometri Masiswa. Skripsi FPMIPA UPI Bandung: Tidak Diterbitkan.

Suherman, E. (2003). Evaluasi Pembelajaran Matematika. Bandung: Diktat Perkuliahan UPI. Tidak Diterbitkan

Sukardi. (2009). Metodologi Penelitian Pendidikan, Kompetensi dan Praktiknya. Jakarta: Bumi Aksara

Sulilawati, W. (2009). Belajar dan Pembelajaran Matematika. Bandung: Diktat Perkuliahan UIN. Tidak Diterbitkan

Sulilawati, W. (2010). Perencanaan Sistem Pembelajaran. Bandung: Diktat Perkuliahan UIN. Tidak Diterbitkan

Surapranata, S. (2006). Analisis, Validitas, Reliabilitas, dan Interpretasi Hasil Tes Implementasi Kurikulum 2004. Bandung: PT Remaja Rosdakarya

Takari R, Enjah. (2008). Penelitian Tindakan Kelas. Bandung: Genesindo

Thohari, K. (2011). Meningkatkan Kualitas Pembelajaran Geometri dengan Teori Van Hiele. [Online]. Tersedia: bdksurabaya.kemenag.co.id/file/ dokumen/vanhile.pdf. [30 Juli 2012]

Van de Walle, J. (2008). Matematika Sekolah Dasar dan Menengah Jilid 1. Jakarta: Erlangga

Van de Walle, J. (2008). Matematika Sekolah Dasar dan Menengah Jilid 2. Jakarta: Erlangga 